\title{
PENGARUH MODEL QUANTUM TEACHING BERBASIS PENDIDIKAN KARAKTER TERHADAP KOMPETENSI PENGETAHUAN IPA SISWA KELAS V SD GUGUS DEWI SARTIKA DENPASAR TIMUR TAHUN AJARAN 2017/2018
}

\author{
Ni Komang Mega Lestari ${ }^{1}$, I Nengah Suadnyana ${ }^{2}$, I Gusti Agung Oka Negara ${ }^{3}$ \\ Jurusan Pendidikan Guru Sekolah Dasar \\ Universitas Pendidikan Ganesha \\ Singaraja, Indonesia \\ e-mail: \{lestari.komang@undiksha.ac.id, inengah.suadnyana@undiksha.ac.id, \\ igustiagungoka.negara@undiksha.ac.id\}
}

\begin{abstract}
Abstrak
Penelitian ini bertujuan untuk mengetahui pengaruh model quantum teaching berbasis pendidikan karakter terhadap kompetensi pengetahuan IPA siswa kelas V SD Gugus Dewi Sartika Denpasar Timur tahun ajaran 2017/2018. Jenis penelitian ini adalah eksperimen dengan desain eksperimen semu menggunakan rancangan kelompok Non-Ekuivalen. Populasi dari penelitian ini adalah seluruh kelas $\mathrm{V}$ SD Gugus Dewi Sartika Denpasar Timur yang berjumlah 328 siswa. Sampel ditentukan dengan teknik random sampling. Sampel dalam penelitian ini adalah siswa kelas VA SDN 10 Kesiman yang berjumlah 42 sebagai kelompok eksperimen dan kelas VB SDN 3 Kesiman yang berjumlah 43 sebagai kelompok kontrol. Data kompetensi pengetahuan IPA dikumpulkan melalui metode tes dalam bentuk tes objektif pilihan ganda biasa. Data yang diperoleh selanjutnya dianalisis dengan statistik deskriptif dan inferensial dalam bentuk gain skor dari kompetensi pengetahuan IPA. Berdasarkan hasil analisis data, maka diperoleh rata-rata gain skor kelompok eksperimen $\bar{X}=0,34>\bar{X}=0,25$ kelompok kontrol. Melalui uji hipotesis dengan uji t pada taraf signifikansi $5 \%$ dan dk 83 diperoleh $t_{\text {hitung }}=3,214>t_{\text {tabel }}=2,000$. Dengan demikian dapat disimpulkan bahwa model quantum teaching berbasis pendidikan karakter berpengaruh terhadap kompetensi pengetahuan IPA siswa kelas V SD Gugus Dewi Sartika Denpasar Timur Tahun Ajaran 2017/2018.
\end{abstract}

Kata kunci: quantum teaching, pendidikan karakter, IPA

\begin{abstract}
This research aims to know the effect of quantum teaching model base character education towards science competency knowledge in $5^{\text {th }}$ grade students of Gugus Dewi Sartika East Denpasar academic year 2017/2018. This study was an experiment with quasy experiment design using the Non-Equivalent Control Group Design. The population of this research is all $5^{\text {th }}$ grade of Gugus Dewi Sartika East Denpasar amounting to 328 students. Sample were taken by random sampling technique. The sample of this research is $5^{\text {th }} \mathrm{A}$ grade in SDN 10 Kesiman amount 42 students as the experiment group and $5^{\text {th }} B$ grade in SDN 3 Kesiman amount 53 student as the control group. The data were collected using the test method in the form of a standard multiple choice objective test. The data were analyzed using descriptive statistic and inferential in shape gain score from science competency knowledge. The result if data analysis obtained mean of gain skor from experiment group $\bar{X}=0,34>\bar{X}=0,25$ control group. From the hypothesis test using $t$-test while at $5 \%$ significance level and df 83 obtained $t_{\text {hitung }}=3,214>t_{\text {tabel }}=2,000$. Based on these result can be concluded that quantum teaching model base character education influence of science competency knowledge of $5^{\text {th }}$ grade students SD Gugus Dewi Sartika East Denpasar academic year 2017/2018.
\end{abstract}

Keyword: quantum teaching, character education, science 


\section{PENDAHULUAN}

Globalisasi adalah suatu tatanan masyarakat yang mendunia dan tidak mengenal batas wilayah serta berlangsung di berbagai bidang kehidupan. Salah satunya yaitu dalam bidang pendidikan. Pendidikan merupakan suatu bentuk usaha sadar dan terencana yang dilakukan oleh seseorang dalam usaha mentransformasikan dirinya agar dapat berguna bagi lingkungan, diri sendiri, maupun orang lain.

Sebagai negara berkembang, Indonesia telah berupaya untuk meningkatkan kualitas sumber daya manusia melalui pemberdayaan dalam bidang pendidikan dan teknologi. Namun dampak negatif dari IPTEK masih belum mampu ditangani secara maksimal. Salah satu upaya yang dilakukan oleh pemerintah adalah memberikan pendidikan karakter kepada seluruh siswa sebagai upaya pencegahan dari penyalahgunaan IPTEK. Meskipun pendidikan karakter sudah mulai dilakukan, namun penerapannya masih perlu ditingkatkan. Agar diperoleh hasil yang memuaskan, maka pendidikan karakter dapat diselipkan di berbagai muatan pelajaran. Sehingga siswa dapat terbiasa menerapkan karakter positif di dalam kegiatan belajar.

Kegiatan belajar mengajar di sekolah berpedoman kepada kurikulum. Kurikulum yang diterapkan di sekolah pada saat ini adalah kurikulum 2013. Tujuan dari kurikulum 2013 adalah menciptakan generasi muda yang mampu bersaing di era global, berprilaku positif serta dapat mengikuti perkembangan zaman. Menurut UU RI no. 20 tahun 2003 tentang Sisdiknas, "kurikulum adalah seperangkat rencana dan pengaturan mengenai tujuan, isi, dan bahan pelajaran, serta cara yang digunakan sebagai pedoman penyelenggaraan kegiatan pembelajaran untuk mencapai tujuan pendidikan tertentu". Siswa tidak lagi mempelajari tiap muatan pelajaran secara terpisah melainkan terintegrasi dengan muatanmuatan pelajaran yang lainnya. Penerapan kurikulum 2013 pada pendidikan dasar di Provinsi Bali hanya diterapkan secara merata di wilayah Denpasar.

Berdasarkan hasil observasi yang dilaksanakan di SD Gugus Dewi Sartika Denpasar Timur ditemukan beberapa permasalahan yaitu belum digunakannya model pembelajaran yang bervariasi, siswa belum diberikan reward positif bagi keaktifannya, dan masih terdapat siswa yang mencerminkan karakter kurang baik dalam kegiatan belajar seperti kurang disiplin, belum bisa menghargai pendapat teman, kurang mandiri, dan lain sebagainya. Hal ini menyebabkan kegiatan pembelajaran menjadi kurang efektif sehingga penguasaan kompetensi siswa belum maksimal. Kondisi ini juga terjadi pada kompetensi pengetahuan IPA.

Kompetensi pengetahuan adalah salah satu hal yang sangat penting dalam komponen kompetensi yang menentukan hasil belajar siswa dalam bidang kognitif. "IPA merupakan ilmu yang pokok bahasannya adalah alam dan segala isinya" (Daryanto, 2014a: 190). Menurut Somatowa (2016) IPA adalah segala sesuatu yang berhubungan dengan alam atau bersangkut paut dengan alam. Jadi dapat disimpulkan bahwa IPA merupakan sebuah IImu yang mempelajari tentang alam dan segala isinya. Kompetensi pengetahuan IPA adalah kemampuan siswa untuk mencapai standar kelulusan dalam muatan pelajaran IPA dari segi pengetahuan (kognitif) setelah mengalami proses belajar muatan pelajaran IPA.

Salah satu cara untuk membangkitkan semangat siswa dalam belajar muatan pelajaran IPA adalah dengan mengadakan variasi penggunaan model pembelajaran. Pada proses pembelajaran, siswa harus dilibatkan secara aktif baik dalam kegiatan mengamati, bertanya, mengumpulkan berbagai informasi dalam kegiatan belajar, menalar, dan mengkomunikasikan hasil belajarnya. Karena kurikulum 2013 menggunakan pendekatan saintifik yang berlandaskan $5 \mathrm{M}$ yakni mengamati, menanya, mengumpulkan informasi, mengasosiasi, dan mengkomunikasikan. Selain itu, proses pembelajarannya diarahkan pada pengembangan tiga ranah yaitu ranah kognitif (pengetahuan), ranah afektif (sikap), dan ranah psikomotor (keterampilan) secara utuh dan holistik, pengembangan ranah yang satu tidak bisa dipisahkan dengan ranah lainnya. Untuk mencapai ketiga ranah tersebut, pembelajaran perlu dilandasi oleh pendidikan karakter. Para ahli dan praktisi dalam bidang 
pendidikan semakin menyadari betapa pentingnya peranan pendidikan karakter guna tercapainya tujuan pendidikan yang sebenarnya yaitu subjek yang dididik mampu dan mau mengamalkan pengetahuan yang diperoleh dari dunia pendidikan dalam kehidupan seharihari (Zubaedi, 2011). Sehingga dalam proses pembelajaran di sekolah dasar yang mengintegrasikan berbagai muatan pelajaran perlu diselipkan pula pendidikan karakter agar ketiga ranah dalam kurikulum 2013 dapat tercapai.

Alternatif model pembelajaran yang dapat digunakan untuk mengatasi permasalahan tersebut adalah model quantum teaching berbasis pendidikan karakter. Model pembelajaran yang diterapkan di sekolah dasar sebaiknya tidak hanya mengarah kepada penguasaan kompetensi pengetahuan saja, melainkan juga memungkinkan untuk pengembangan karakter positif dalam diri siswa sejak dini agar dapat berguna dalam kehidupan sosial dan sebagai landasan hidup di masyarakat yang lebih luas. Untuk mencapai hal tersebut model quantum teaching dapat disertai dengan pendidikan karakter dalam kegiatan pembelajaran.

Secara etimologi, quantum teaching berasal dari bahasa inggris. Quantum adalah sebuah kata yang memiliki arti interaksi yang mengubah energi menjadi cahaya. Sedangkan teaching adalah pembelajaran. Jadi quantum teaching adalah orkestrasi bermacam-macam interaksi yang ada di dalam dan di sekitar momen belajar. Interaksi-interaksi ini mencakup unsur-unsur untuk belajar efektif yang mempengaruhi kesuksesan siswa. Interaksi-interaksi ini akan mengubah kemampuan dan bakat alamiah siswa menjadi cahaya yang akan bermanfaat bagi siswa dan orang lain.

Model quantum teaching adalah sebuah model pembelajaran dengan asas utama yaitu bawalah dunia mereka ke dunia kita, dan antarkan dunia kita ke dunia mereka. Ketika seorang guru berhasil memasuki dunia siswa, maka guru dapat memimpin, menuntun, dan memudahkan perjalanan siswa menuju kesadaran dan ilmu pengetahuan yang lebih luas. Quantum teaching berfokus pada hubungan yang dinamis dalam lingkungan kelas, interaksi yang mendirikan landasan dan kerangka untuk belajar. Model quantum teaching adalah penggubahan cara belajar yang meriah dengan segala nuansanya. Model ini juga menyertakan segala kaitan interaksi dan perbedaan yang memaksimalkan momen belajar dengan asas utama bawalah dunia mereka ke dunia kita dan antarkan dunia kita ke dunia mereka (DePorter,dkk,2014). Model quantum teaching memiliki tahapan belajar yang disebut dengan TANDUR yaitu tumbuhkan, alami, namai, demonstrasikan, ulangi, dan rayakan.

Tahap pertama yaitu menumbuhkan minat belajar dengan memuaskan AMBAK (apakah manfaatnya bagiku) dan manfaatkan kehidupan siswa. Pada tahap ini guru berusaha untuk mengikutsertakan siswa dalam berbagai kegiatan belajar. Tahap tumbuhkan dilakukan untuk menggali permasalahan terkait dengan materi yang akan dipelajari. Pada tahap kedua yaitu alami, guru menciptakan atau mendatangkan pengalaman umum yang dapat dimengerti semua siswa. Pada tahap ini guru memberikan kesempatan kepada siswa untuk mengembangkan keingintahuannya. Tahap ini dapat dilakukan dengan mengadakan pengamatan. Tahap ketiga yaitu namai adalah tahap menyediakan kata kunci, konsep, model, rumus, strategi atas pengalaman yang telah diperoleh siswa pada tahap sebelumnya. Tahap penamaan memacu struktur kognitif siswa dalam memberikan identitas, menguatkan, dan mendefinisikan segala kegiatan yang telah dilaluinya. Penamaan setelah memperoleh pengalaman belajar adalah saat yang tepat untuk penanaman konsep dalam diri siswa, karena dengan memberi nama sesuatu menjadi lebih bermakna dan berkesan bagi siswa. Tahap keempat adalah demonstrasikan yang memberi kesempatan untuk menerapkan pengetahuan ke dalam pembelajaran dan kehidupan nyata siswa. Tahap ini menyediakan kesempatan bagi siswa untuk menunjukkan bahwa mereka tahu yang dapat dilakukan dengan penyajian di depan kelas, menjawab pertanyaan, dan menunjukkan hasil belajar. Tahap kelima adalah pengulangan yang dapat memperkuat koneksi syaraf sehingga menguatkan struktur kognitif siswa. Semakin sering siswa melakukan pengulangan, maka pengetahuan yang dimilikinya akan semakin mendalam. Guru perlu menunjukkan kepada siswa cara-cara mengulang materi pelajaran yang menegaskan bahwa mereka memang 
tahu materi itu. Tahap ulangi dapat dilakukan dengan menegaskan kembali materi pokok pelajaran yang telah dipelajari sebelumnya atau melalui latihan soal. Tahap terakhir adalah rayakan yang merupakan sebuah pengakuan untuk penyelesaian, partisipasi, dan pemerolehan keterampilan dan ilmu pengetahuan oleh siswa. tahap ini bisa dilakukan dengan pemberian pujian, tepuk tangan, pemberian reward nyata, dan bernyanyi bersama.

Adapun kelebihan dari model quantum teaching adalah (1) membimbing siswa kearah berpikir yang sama, (2) siswa lebih dilibatkan dalam proses belajar, (3) pembelajaran lebih nyaman dan menyenangkan, (4) peserta didik dirancang untuk aktif mengamati, menyesuaikan teori dengan kenyataan, dan dapat mencoba melakukannya sendiri, (5) guru dapat berpikir dan merancang pembelajaran dengan kreatif, dan (6) pelajaran yang diberikan guru mudah dimengerti dan diterima oleh siswa.

Pendidikan karakter adalah proses pengajaran yang melibatkan kurikulum dan organisasi sekolah dalam upaya membiasakan siswa dalam berpikir dan bersikap serta mengamalkannya melalui perilaku yang sesuai dengan nilai-nilai luhur yang diwujudkan melalui interaksi dengan Tuhan, diri sendiri, dan lingkungan. Melalui Kementerian Pendidikan Nasional, pemerintah Indonesia merumuskan nilai-nilai karakter atau pilar pendidikan karakter yang terdiri dari karakter religius, jujur, toleransi, disiplin, kerja keras, kreatif, mandiri, demokratis, rasa ingin tahu, semangat kebangsaan, cinta tanah air, menghargai prestasi, bersahabat atau komunikatif, cinta damai, gemar membaca, peduli lingkungan, peduli sosial, dan tanggung jawab (Yaumi, 2014). Beberapa karakter yang dapat diintegrasikan dalam kegiatan pembelajaran dengan model quantum teaching adalah jujur, disiplin, kerja keras, demokratis, rasa ingin tahu, menghargai prestasi, komunikatif, dan tanggung jawab. Menurut penelitian mengenai pengaruh model quantum teaching yang dilakukan oleh Meiyani (2017) dinyatakan bahwa model ini berpengaruh terhadap kompetensi pengetahuan IPA serta dapat memudahkan siswa untuk memahami sesuatu dengan cara yang menarik. Dengan menggunakan model quantum teaching, diyakini dapat melejitkan prestasi belajar siswa karena di dalam kegiatan belajarnya sangat mengutamakan interaksi belajar yang positif dan menyenangkan menuju arah kemajuan belajar.

Model quantum teaching berbasis pendidikan karakter adalah inovasi pembelajaran hasil kombinasi dari pembelajaran yang menarik dan menyenangkan serta dikaitkan dengan nilai-nilai pendidikan karakter yang tentunya dapat menunjang keberhasilan dalam kegiatan belajar mengajar di sekolah, salah satunya adalah keberhasilan dalam mencapai kompetensi pengetahuan IPA.

\section{METODE}

Penelitian ini dilaksanakan di SD Gugus Dewi Sartika Denpasar Timur, adapun SD yang tergabung di gugus ini berjumlah 6 SD diantaranya adalah SDN 3 Kesiman, SDN 7 Kesiman, SDN 10 Kesiman, SDN 12 Kesiman, SDN 16 Kesiman, SDN 17 Kesiman. Penelitian ini dilaksanakan pada bulan Maret 2018 sampai dengan bulan April 2018, perlakuan pada kelas eksperimen dan kelas kontrol diberikan masing-masing sebanyak 9 kali. Penelitian ini termasuk ke dalam kelompok penelitian kuantitatif dengan menggunakan metode penelitian eksperimen. Rancangan yang digunakan dalam penelitian ini adalah rancangan eksperimen semu (quasi experiment design) karena tidak memungkinkan untuk mengontrol semua karakteristik dan kondisi eksperimen secara ketat. Bentuk desain ekperimen yang digunakan adalah rancangan kelompok non ekuivalen. Dalam rancangan ini penempatan subjek ke dalam kelompok eksperimen dan kelompok kontrol tidak dilakukan secara acak dan tidak membentuk kelas baru. Kelompok eksperimen diberi perlakuan berupa model quantum teaching berbasis pendidikan karakter sedangkan kelompok kontrol dibelajarkan dengan pembelajaran konvensional yaitu pembelajaran yang biasa digunakan disekolah tersebut sehari-harinya.

Tahap pada penelitian ini terbagi menjadi tiga yaitu tahap persiapan eksperimen, tahap pelaksanaan eksperimen, dan tahap akhir eksperimen. Pada tahap persiapan 
eksperimen yang dilakukan adalah melakukan wawancara dengan kepala gugus dan wali kelas V di SD Gugus Dewi Sartika Denpasar Timur untuk mengetahui ada tidaknya kelas unggulan, menyusun rancangan pelaksanaan pembelajaran (RPP) untuk kelas eksperimen dan kelas kontrol, menyusun instrumen penelitian berupa tes kompetensi pengetahuan IPA pada ranah kognitif untuk mengukur kompetensi pengetahuan IPA siswa, mengkonsultasikan instrumen penelitian bersama wali kelas dan dosen pembimbing, mengkonsultasikan RPP bersama wali kelas dan dosen pembimbing, mengadakan uji coba instrumen penelitian, menentukan sampel yang berupa kelas dari populasi yang tersedia dengan cara mengundi, dari dua sampel yang telah terpilih kemudian diundi untuk menentukan kelas eksperimen yang dibelajarkan dengan model quantum teaching berbasis pendidikan karakter dan kelas kontrol yang dibelajarkan dengan pembelajaran konvensional. Pada tahap kedua yaitu tahap pelaksanaan eksperimen dilakukan hal-hal seperti memberikan pretest kepada kedua kelas yang terpilih sebagai sampel untuk mengetahui kesetaraannya, melakukan uji kesetaraan sampel dengan menganalisis data pretest menggunakan teknik uji t, melaksanakan penelitian dengan memberikan perlakuan yang berupa model quantum teaching pada kelas eksperimen. Pada tahap akhir penelitian dilakukan pemberian posttest, menganalisis data, dan melakukan uji hipotesis.

Populasi dari penelitian ini adalah seluruh siswa kelas V SD Negeri di Gugus Dewi Sartika Denpasar Timur yang terdiri dari delapan kelas di dalam enam sekolah dasar. Populasi dalam penelitian ini berjumlah 328 orang. Teknik pengambilan sampel dalam suatu penelitian disebut dengan teknik sampling. Teknik sampling yang digunakan pada penelitian ini adalah teknik random sampling. Teknik random sampling adalah cara pengambilan sampel secara acak (Sugiyono, 2016). Pengacakan dilakukan pada kelas, bukan individu yang ada di dalam kelas tersebut karena dalam penelitian ini tidak memungkinkan untuk mengacak individu dan mengubah kelas yang sudah ada sebelumnya. Setelah diketahui bahwa seluruh kelas V di SD di Gugus Dewi Sartika tidak terdapat kelas unggulan atau semua kelas dinyatakan setara, maka pengundian sudah dapat dilakukan. Cara pengundian ini adalah dengan menuliskan seluruh nama kelas $V$ di seluruh SD populasi pada kertas dan menggulungnya. Kemudian letakkan semua gulungan pada sebuah wadah. Lakukan pengundian dengan mengeluarkan dua gulungan dari wadah secara bergantian. Dua gulungan kertas tersebut adalah sampel dari penelitian. Kedua sampel tersebut diberikan pretest dan diuji kesetaraannya. Setelah diketahui setara maka dilakukan undian untuk menentukan kelas eksperimen dan kelas kontrol. Kelas yang muncul pertama dipilih menjadi kelas eksperimen dan kelas yang muncul kedua adalah kelas kontrol.

Berdasarkan undian yang dilakukan, kelas VA SD N 10 Kesiman yang berjumlah 42 siswa muncul pertama dan dijadikan sebagai kelas eksperimen, sedangkan kelas VB SD N Negeri 3 Kesiman yang berjumlah 43 siswa muncul pada undian kedua dan dijadikan sebagai kelas kontrol. Pada kelas eksperimen diberikan perlakuan berupa model quantum teaching berbasis pendidikan karakter dan pada kelas kontrol dibelajarkan dengan menggunakan pembelajaran konvensional yaitu menggunakan pendekatan saintifik.

Penelitian eksperimen terdapat kontrol validitas. Validitas penellitian adalah kemampuan suatu penelitian untuk mengungkapkan secara tepat mengenai apa yang ingin diteliti. Terdapat dua validitas yang terkait dengan penelitian yang terdiri dari validitas internal dan validitas eksternal. Validitas internal pada penelitian ini meliputi karakteristik subjek, instrumentasi, testing, sejarah, kematangan atau maturasi, dan sikap subjek. Sedangkan kontrol validitas eksternal pada penelitian ini dilakukan dengan membatasi penelitian pada kelas V SD Gugus Dewi Sartika serta pemilihan anggota sampel secara acak untuk mewakili populasi. Teknik pengambilan sampel yang digunakan adalah teknik random sampling dengan melakukan pengundian pada populasi yang sudah terbentuk dalam kelas-kelas, sehingga setiap kelas dalam populasi memiliki kesempatan yang sama untuk dijadikan sampel penelitian, sehingga hasilnya dapat digeneralisasikan pada populasi yaitu siswa kelas V SD Dewi Sartika Denpasar Timur.

Data yang dikumpulkan pada penelitian ini adalah data kompetensi pengetahuan IPA siswa kelas V SD Gugus Dewi Sartika Denpasar Timur tahun pelajaran 2017/2018. Metode 
pengumpulan data yang digunakan adalah metode tes. Jenis tes yang digunakan adalah tes objektif pilihan ganda biasa dengan empat pilihan jawaban yaitu A,B,C, dan D yang mengandung satu jawaban benar. Tes kompetensi pengetahuan IPA ini disusun sendiri berdasarkan indikator-indikator dalam muatan materi IPA yang telah tertuang pada kisi-kisi. Tes kompetensi pengetahuan IPA yang digunakan dalam penelitian ini berjumlah 33 butir soal yang telah diuji validitas, reliabilitas, daya beda, dan tingkat kesukarannya.

Teknik analisis data yang digunakan pada penelitian ini adalah teknik analisis statistik deskriptif dan analisis statistik inferensial dengan mengolah data gain skor dari kompetensi pengetahuan siswa. Menurut Setyosari (2016) statistik deskriptif adalah statistik yang digunakan untuk mendeskripsikan sekelompok data atau keadaan. Perhitungan yang dilakukan pada analisis statistik deskriptif meliputi menghitung rata-rata (mean), standar deviasi, dan varians. Statistik inferensial adalah suatu cara mengolah data yang dilakukan dengan menerapkan rumus-rumus statistik inferensial untuk menguji suatu hipotesis penelitian yang diajukan oleh peneliti dan ditarik kesimpulan berdasarkan pengujian hipotesis (Agung, 2014). Pada analisis statistik inferensial yang dilakukan adalah pengujian hipotesis dengan menggunakan uji t dengan rumus polled varians, namun sebelumnya perlu dilakukan uji prasyarat analisis yang berupa uji normalitas sebaran data dan uji homogenitas varians.

\section{HASIL DAN PEMBAHASAN}

Hasil penelitian ini memaparkan tentang nilai rata-rata (mean), standar deviasi, varians, nilai maksimum, dan nilai minimum dari data kompetensi penegtahuan IPA siswa kelas VA SDN 10 Kesiman sebagai kelompok eksperimen yang dibelajarakan dengan model quantum teaching berbasis pendidikan karakter. Dan siswa kelas VB di SDN 3 Kesiman sebagai kelompok kontrol yang dibelajarkan dengan pembelajaran konvensional. Posttest diberikan setelah 9 kali perlakuan di kelompok eksperimen dan 9 kali perlakuan di kelompok kontrol. Banyaknya siswa di kelompok eksperimen adalah 42 siswa, dan pada kelompok kontrol jumlahnya adalah 43 siswa jadi jumlah sampel dalam penelitian ini adalah 85 siswa. Hasil deskripsi data dapat dilihat pada tabel berikut.

Tabel 1. Tabel Deskripsi Data Gain Skor Kompetensi Pengetahuan IPA Kelompok Eksperimen dan Kelompok Kontrol

\begin{tabular}{lcc}
\hline \multicolumn{1}{c}{ Hasil Analisis } & Kelompok Eksperimen & Kelompok Kontrol \\
\hline Rata-rata & 0,34 & 0,25 \\
Standar Deviasi & 0,18 & 0,12 \\
Varians & 0,03 & 0,02 \\
Nilai Maksimum & 0,73 & 0,52 \\
Nilai Minimum & 0,06 & 0,05 \\
\hline
\end{tabular}

Berdasarkan hasil perhitungan tersebut, maka nilai rata-rata gain skor kelas eksperimen yaitu 0,34 dan rata-rata gain skor kelas kontrol yang diperoleh yaitu 0,25. Hasil perhitungan dan analisis data kompetensi pengetahuan IPA menunjukkan bahwa rata-rata gain skor kompetensi pengetahuan IPA siswa pada kelompok eksperimen lebih tinggi dari rata-rata gain skor kompetensi pengetahuan IPA siswa pada kelompok kontrol yaitu $0,34>0,25$.

Berdasarkan hasil uji normalitas dengan metode Kolmogorov-Smirnov dan homogenitas dengan uji $\mathrm{F}$ dapat diketahui bahwa data yang diperoleh dari kelompok eksperimen dan kelompok kontrol berdistribusi normal dan memiliki varians yang homogen. Karena data telah memenuhi uji prasyarat maka uji hipotesis dapat dilakukan dengan menggunakan analisis uji t dengan rumus polled varians. 
Nilai rata-rata yang diperoleh pada kelompok eksperimen adalah 0,34 dengan varians 0,03 . Sedangkan rata-rata pada kelompok kontrol adalah 0,25 dengan varians 0,02. Jumlah siswa pada kelompok eksperimen yaitu 42 siswa dan pada kelas kontrol jumlahnya yaitu 43 siswa. Kriteria pengujian dilakukan pada taraf signifikansi $5 \%$ dengan derajat kebebasan (dk) $n_{1}+n_{2}-2$ yaitu $42+43-2=83$. Jika harga $t_{\text {hitung }} \leq t_{\text {tabel }}$ maka $\mathrm{H}_{\mathrm{o}}$ diterima dan $\mathrm{H}_{\mathrm{a}}$ ditolak. Dan jika harga $t_{\text {hitung }}>\mathrm{t}_{\text {tabel }}$ maka $\mathrm{H}_{\circ}$ ditolak dan $\mathrm{H}_{\mathrm{a}}$ diterima. Berdasarkan analisis data gain skor kompetensi pengetahuan IPA siswa diperoleh hasil sebagai berikut.

Tabel 2. Hasil Uji Hipotesis

\begin{tabular}{|c|c|c|c|c|c|c|c|}
\hline No & Sampel & $\mathrm{N}$ & $\mathrm{dk}$ & Rata-rata & Varians & $t_{\text {hitung }}$ & $t_{\text {tabel }}$ \\
\hline 1 & Kelompok Eksperimen & 42 & 83 & 0,34 & 0,03 & 3,214 & 2,000 \\
\hline 2 & Kelompok Kontrol & 43 & & 0,25 & 0,02 & & \\
\hline
\end{tabular}

Berdasarkan tabel tersebut, pada hasil uji-t dengan taraf signifikansi $5 \%$ dan $\mathrm{dk}=$ 42+43-2. diperoleh $t_{\text {hitung }}=3,214>t_{\text {tabel }}=2,000$, dengan demikian dapat disimpulkan bahwa hipotesis yang menyatakan terdapat perbedaan yang signifikan kompetensi pengetahuan IPA kelompok siswa yang dibelajarkan melalui model quantum teaching berbasis pendidikan karakter dengan kelompok siswa yang dibelajarkan melalui pembelajaran konvensional pada siswa kelas V SD Gugus Dewi Sartika Denpasar Timur tahun ajaran 2017/2018 diterima. Ratarata gain skor kompetensi pengetahuan IPA kelompok eksperimen yang dbelajarkan dengan model quantum teaching berbasis pendidikan karakter yaitu 0,34. Sedangkan pada kelompok kontrol yang dibelajarkan dengan pembelajaran konvensional diperoleh rata-rata yaitu 0,25.

Jika dilihat dari rata-rata yang diperoleh pada masing-masing kelompok dapat diketahui bahwa kelompok eksperimen memperoleh rata-rata yang lebih tinggi daripada kelompok kontrol. Ini berarti kelompok yang dibelajarkan melalui model quantum teaching berbasis pendidikan karakter memiliki pengaruh yang lebih baik daripada kelompok yang dibelajarkan melalui pembelajaran konvensional terhadap kompetensi pengetahuan IPA siswa. Karena terdapat perbedaan yang signifikan dan rata-rata gain skor kelompok eksperimen lebih tinggi daripada kelompok kontrol, maka terdapat pengaruh model pembelajaran quantum teaching berbasis pendidikan karakter terhadap kompetensi pengetahuan IPA siswa kelas V SD Gugus Dewi Sartika tahun ajaran 2017/2018.

Rata-rata gain skor kompetensi pengetahuan IPA siswa pada kelompok eksperimen lebih tinggi dari kelompok kontrol dengan perolehan $(\bar{X}=0,34>\bar{X}=0,25)$ serta melalui uji $\mathrm{t}$ diperoleh $t_{\text {hitung }}=3,214>t_{\text {tabel }}=2,000$, sehingga dapat disimpulkan bahwa model quantum teaching berbasis pendidikan karakter berpengaruh terhadap kompetensi pengetahuan IPA siswa kelas V SD Gugus Dewi Sartika Denpasar Timur tahun ajaran 2017/2018.

Pada kelompok eksperimen, kegiatan pembelajaran dalam muatan materi IPA menggunakan model quantum teaching berbasis pendidikan karakter. Proses pembelajaran menjadi lebih menyenangkan karena siswa belajar dengan antusias, siswa dapat memahami konsep serta materi IPA secara bertahap dengan nuansa belajar yang positif dan penuh motivasi. Siswa dapat saling bertukar pendapat, menjelaskan atau mendemonstrasikan hasil temuannya di depan kelas sehingga siswa terbiasa untuk menerima masukan serta saran dari teman maupun guru. Pembelajaran dengan menggunakan model quantum teaching diakhiri dengan tahap merayakan berbagai hasil belajar siswa, dengan hal ini siswa dapat memaksimalkan kembali pengetahuannya pada materi selanjutnya. Selain itu karakter siswa yang tercermin pada kegiatan belajar mengajar sudah baik, sehingga siswa dan guru dapat lebih fokus dalam belajar maupun mengajar. Pada kelompok kontrol, kegiatan pembelajaran menggunakan pembelajaran konvensional dengan pendekatan saintifik. Pembelajaran yang dilakukan pada kelompok kontrol masih bersifat klasikal, sehingga kerjasama antar siswa 
masih belum terjalin dengan baik, siswa masih kurang terbiasa mengemukakan pendapatnya di depan kelas, serta keaktifan siswa belum merata karena siswa yang aktif dalam kelas hanyalah beberapa saja.

Kegiatan pembelajaran menggunakan model quantum teaching berbasis pendidikan karakter memberikan peningkatan pada kompetensi pengetahuan siswa khususnya dalam kompetensi pengetahuan IPA. Karena kompetensi pengetahuan IPA siswa yang dibelajarkan dengan model quantum teaching berbasis pendidikan karakter lebih tinggi jika dibandingkan dengan kelompok siswa yang hanya dibelajarkan dengan pembelajaran konvensional. Hal ini dikarenakan model quantum teaching berbasis pendidikan karakter memiliki kelebihan dalam kegiatan pembelajarannya yaitu dengan tahapan-tahapannya yang terdiri dari TANDUR yaitu tumbuhkan, alami, namai, demonstrasikan, ulangi, dan rayakan, serta dipadukan dengan basis pendidikan karakter yang mampu membuat siswa lebih fokus dan tertib dalam belajar. Menurut Musfah (2015) pendidikan karakter dapat meningkatkan kecerdasan emosi siswa sehingga siswa dapat berhasil dalam menghadapi segala macam tantangan, termasuk tantangan untuk berhasil secara akademis.

Perbedaan hasil kompetensi pengetahuan IPA siswa dapat dilihat dari tahapan belajar yang dilakukan pada kedua kelompok tersebut yaitu pada kelompok eksperimen menggunakan tahapan belajar yang terdiri dari TANDUR (tumbuhkan, alami, demonstrasikan, ulangi, dan rayakan) berbasis pendidikan karakter sedangkan pada kelompok kontrol menggunakan pendekatan saintifik dengan komponen belajar yang terdiri dari $5 \mathrm{M}$ (mengamati, menanya, mengumpulkan informasi, mengasosiasi, dan mengkomunikasikan). Hasil analisis uji hipotesis dan nilai rata-rata gain skor kelompok siswa yang belajar dengan model quantum teaching berbasis pendidikan karakter dengan kelompok siswa yang mengikuti pembelajaran konvensional.

Hasil temuan pada penelitian ini memiliki persamaan dengan penelitian yang telah dilakukan sebelumnya. Penelitian tersebut adalah penelitian yang dilakukan oleh Setyawan (2017) bahwa terdapat perbedaan kompetensi pengetahuan IPA siswa yang dibelajarkan dengan model quantum teaching berbasis Catur Pramana dengan siswa yang dibelajarkan dengan pembelajaran konvensional. Selain itu penelitian yang dilakukan oleh Sudewiputri (2016) juga menyatakan bahwa model pembelajaran kuantum berpengaruh terhadap hasil belajar siswa pada muatan pelajaran IPA. Dengan demikian, model quantum teaching berbasis pendidikan karakter dapat direkomendasikan dalam membelajarkan siswa.

Hasil penelitian ini dapat digunakan sebagai bahan masukan bagi guru untuk memilih model pembelajaran agar lebih bervariasi dalam mengajar dan dapat digunakan untuk membantu meningkatkan kompetensi pengetahuan IPA siswa sesuai dengan apa yang diharapkan. Model quantum teaching berbasis pendidikan karakter dapat digunakan oleh guru karena sudah terbukti dapat mempengaruhi kompetensi pengetahuan IPA siswa menjadi lebih baik. Dalam penerapan model ini guru harus mampu menggabungkan sintaks pada model quantum teaching berbasis pendidikan karakter dengan pembelajaran pada kurikulum 2013. Selain itu, persiapan dalam pelaksanaan model juga perlu diperhatikan.

\section{SIMPULAN DAN SARAN}

Berdasarkan penelitian yang telah dilaksanakan, maka dapat disimpulkan bahwa kompetensi pengetahuan IPA kelompok eksperimen yang dibelajarkan melalui model quantum teaching berbasis pendidikan karakter memperoleh skor rata-rata gain skor $\bar{X}=0,34$ dengan nilai gain skor tertinggi $=0,73$ dan nilai gain skor terendah $=0,06$. Kompetensi pengetahuan IPA kelompok kontrol yang dibelajarkan melalui pembelajaran konvensional memperoleh skor rata-rata gain skor $\bar{X}=0,25$ dengan nilai gain skor tertinggi $=0,52$ dan nilai gain skor terendah $=$ 0,05 . Terdapat pengaruh model quantum teaching berbasis pendidikan karakter terhadap kompetensi pengetahuan IPA siswa kelas V SD Gugus Dewi Sartika Denpasar Timur tahun ajaran 2017/2018. Hal ini dibuktikan dengan hasil uji hipotesis menggunakan uji t memperoleh $t_{\text {hitung }}=3,214$. Harga tersebut kemudian dibandingkan dengan $t_{\text {tabel }}=2,000$. Karena $t_{\text {hitung }}=3,214$ 
$>t_{\text {tabel }}=2,000$ maka Ho ditolak dan ha diterima. Rata-rata gain skor kompetensi pengetahuan IPA pada kelompok eksperimen $\bar{X}=0,34>\bar{X}=0,25$ rata-rata gain skor kompetensi pengetahuan IPA kelompok kontrol, sehingga model quantum teaching berbasis pendidikan karakter memiliki pengaruh terhadap kompetensi pengetahuan IPA siswa kelas V SD Gugus Dewi Sartika Denpasar Timur tahun pelajaran 2017/2018.

Berdasarkan hasil penelitian, pembahasan, dan simpulan, maka dapat diajukan beberapa saran kepada beberapa pihak yaitu (1) kepada guru disarankan agar lebih aktif dan kreatif dalam mengemas pembelajaran dan memfasilitasi siswa dalam belajar. Dengan memilih model pembelajaran yang tepat seperti model quantum teaching berbasis pendidikan karakter, maka guru dapat mengoptimalkan kompetensi pengetahuan yang dimiliki oleh siswa (2) kepada kepala sekolah disarankan selalu memberi sosialisasi tentang berbagai model pembelajaran inovatif kepada guru dalam mengajar agar kompetensi pengetahuan IPA siswa dapat semakin berkembang sehingga mutu sekolah menjadi meningkat (3) kepada peneliti lain disarankan untuk melakukan penelitian dengan pokok bahasan yang lebih beragam sehingga diperoleh hasil penelitian yang lebih baik serta menemukan inovasi kegiatan pembelajaran lain yang bermakna bagi siswa.

\section{DAFTAR PUSTAKA}

Daryanto. 2014a. Pembelajaran Tematik, Terpadu, Terintegrasi (Kurikulum 2013). Yogyakarta: Gava Media

DePorter, Bobbi. Dkk. 2014. Quantum Teaching Mempraktikkan Quantum Learning di RuangRuang Kelas. Bandung: Kaifa

Meiyani, Kadek Sri. 2017. "Pengaruh Model Quantum Teaching Melalui Karyawisata Terhadap Penguasaan Kompetensi Pengetahuan IPS Siswa Kelas V". Jurnal Mimbar PGSD Universitas Pendidikan Ganesha, Volume 5, No:2. Terdapat pada https://ejournal.undiksha.ac.id/index.php/JJPGSD/article/download/10836/6938 (diakses tanggal 10 Desember 2017)

Musfah. Jejen. 2015. Manajemen Pendidikan Teori, Kebijakan, dan Praktik. Jakarta: Kencana

Peraturan Menteri Pendidikan dan Kebudayaan Nomor 103 Tahun 2014 tentang Pembelajaran pada Pendidikan Dasar dan Menengah. 2014. Jakarta: Kemendikbud

Samatowa, Usman. 2016. Pembelajaran IPA di Sekolah Dasar. Jakarta: Indeks

Setyawan, I Wayan Pasek Edi. 2017. "Pengaruh Quantum Teaching Berbasis Catur Pramana Terhadap Kompetensi Pengetahuan IPA Siswa Kelas V SD Gugus Srikandi Denpasar Timur Tahun Pelajarn 2016/2017". Jurnal Mimbar PGSD Universitas Pendidikan Ganesha, Volume 5, No:2. Tersediapada download.portalgaruda.org/article.php?...Pengaruh\%20quantum\%20te aching... (diakses tanggal 9 April 2018)

Setyosari, Punaji. 2016. Metode Penelitian Pendidikan dan Pengembangan. Jakarta. Prenada Media Group

Sudewiputri, Made Padmarani. 2016. "Pengaruh Model Pembelajaran Kuantum TerhadapHasil Belajar IPA Kelas IV di Gugus I Kecamatan Buleleng". Jurnal Mimbar PGSD Universitas Pendidikan Ganesha, Volume 4, No:1. Tersediapada download.portalgaruda.org/article.php?...Pengaruh\%20model\%20\%pe mbelajaran... (diakses tanggal 9 April 2018) 
Sugiyono. 2016. Metode Penelitian Pendidikan Pendekatan Kuantitatif, Kualitatif, dan R\&D. Bandung: Alfabeta

Yaumi, Muhammad. 2014. Pendidikan Karakter Landasan, Pilar dan Implementasi. Jakarta: Prenada Media Group

Zubaedi. 2011. Desain Pendidikan Karakter Konsepsi dan Aplikasinya dalam Lembaga Pendidikan. Jakarta: Kencana Prenada Group. 